\title{
СД-28. \\ ОПРЕДЕЛЕНИЕ КОЭФФИЦИЕНТОВ УРАВНЕНИЯ МАРКА-КУНА-ХАУВИНКА ДРЕВЕСНЫХ ГЕМИЦЕЛЛЮЛОЗ МЕТОДОМ ГЕЛЬ-ПРОНИКАЮЩЕЙ ХРОМАТОГРАФИИ
}

\author{
Маляр Ю.Н. ${ }^{1,2}$, Чудина А.И. ${ }^{1}$, Боровкова В.С. ${ }^{1,2}$, Судакова И.Г. ${ }^{1}$ \\ ${ }^{1}$ Институт химии и химической технологии СО РАН, Красноярск, Россия \\ ${ }^{2}$ Сибирский федеральный университет, Красноярск, Россия \\ yumalyar@gmail.com
}

DOI: 10.26902/ASFE-11_121

Гемицеллюлозы (ГЦ) - полисахариды клеточной стенки растений, являются самыми распространенными возобновляемыми растительными полимерами после целлюлозы и являются побочным продуктом процессов делигнификации древесины. В настоящее время ГЦ не находят широкого применения вследствие сложности выделения, а также неупорядоченной полимерной структуры. Однако существуют перспективные разработки для применения ГЦ в пленках для упаковки [1], в качестве материала для трехмерной печати [2], в различных биомедицинских целях благодаря таким преимуществам как нетоксичность, биосовместимость, способность к биологическому разложению [3]. Гемицеллюлозы, полученные в процессе каталитического фракционирования древесины с использованием катализаторов, имеют низкое содержание лигнина и пригодны для дальнейшей переработки.

Критическими параметрами для любого полимерного материала являются их молекулярно-массовые характеристики, а при использовании полимера в качестве стабилизаторов, пленок, адсорбентов важным являются вязкостные характеристики. Уравнение, связывающее молекулярно-массовые характеристики полимера с его вязкостью Марка-Куна-Хаувинка: $[\eta]=\mathrm{K}_{\eta} \mathrm{M}^{\alpha}$. Коэффициенты $\mathrm{K}_{\eta}$ и $\alpha$ являются ключевыми характеристиками, определяющими конформации и размеры молекул. Однако классический метод вискозиметрии плохо описывает системы сложных полимеров. Поэтому для определения констант уравнения Марка-Куна-Хаувинка предложено использовать метод гель-проникающей хроматографии с вискозиметрическим детектором. Такая комбинация методов дает высокую точность получаемых значений, а также хорошую воспроизводимсть.

Для ГЦ, полученных методом окислительной делигнификации древесины лиственницы, подобраны состав элюента и параметры хроматографирования, позволяющие подавить полиэлектролитный эффект. Разработана методика определения констант уравнения МаркаКуна-Хаувинка для ГЦ, и установлены зависимости от параметров делигнификации, таких как концентрация катализатора, температура и продолжительность процесса. Установлено, коэффициент $\alpha$ меняется в пределах 0,73-0,88 при увеличении продолжительности процесса, a $\mathrm{K}_{\eta}$ зависит от концентрации катализаторов, что позволяет варьировать параметры процесса для получения гемицеллюлоз с заданными молекулярно-массовыми характеристиками.

\section{Список литературы}

1. Mendes F.R.S., Bastos M.S.R., Mendes L.G., Silva A.R.A., Moreira R.A. Preparation and evaluation of hemicellulose films and their blends // Food Hydrocoll. 2017. V. 70, P. 181.

2. Xu W., Pranovich A., Uppstu P., Wang X., Kronlund D., Hemming J., Öblom H., Moritz N., Preis M., Sandler N., Willför S., Xu C. Novel biorenewable composite of wood polysaccharide and polylactic acid for three-dimensional printing // Carbohydr. Polym. 2018. V. 187, P. 51.

3. Sun X.-F., Wang H.-H., Jing Z.-X., Mohanathas R. Hemicellulose-based pH-sensitive and biodegradable hydrogel for controlled drug delivery // Carbohydr. Polym. 2013. V. 92. P. 1357

Исследование выполнено при финансовой поддержке РФФИ в рамках научного проекта № 20-33-70256. 